This is an author produced version of a paper published in Politics. This paper has been peer-reviewed but does not include the final publisher proof-corrections or journal pagination.

Citation for the published paper:

Lind, Jacob. (2017). The duality of children's political agency in deportability. Politics, vol. 37 , issue 3 , p. null

URL: https://doi.org/10.1177/0263395716665391

Publisher: Sage

This document has been downloaded from MUEP (https://muep.mah.se) / DIVA (https://mau.diva-portal.org). 


\title{
The duality of children's political agency in deportability
}

\author{
(Author's version)
}

\section{Jacob Lind}

Global Political Studies, Malmö University, 20506 Malmö, Sweden

E-mail: jacob.lind@mah.se

\begin{abstract}
Drawing on in-depth ethnographic observations among irregularised migrant families in Birmingham, UK, this article discusses how children's political agency manifests in everyday life. It shows how children who become aware of their legal status as 'deportable' reject this subject position and offer their own definitions of who they are and where they belong. Simultaneously, it is argued that children with varying degrees of knowledge about their legal status also express political agency through their struggle to sustain the inclusion they experience. Such expressions highlight the duality of children's political agency in irregular situations.
\end{abstract}

\section{Keywords}

Children, deportability, the irregular situation, political agency

\section{Full article at:}

http://pol.sagepub.com/content/early/2016/09/06/0263395716665391.full.pdf+html

DOI: $10.1177 / 0263395716665391$

In this article, I discuss how the context of the irregular situation, which is characterised by the 'deportability' of the people who end up in it (De Genova, 2002), is a fruitful case to analyse for broadening our understanding of how children's political agency comes about. Through ethnographic observations of the everyday lives of irregularised migrant children in Birmingham, UK, I highlight the duality of children's political agency by focusing on what the children do rather than who they are (Bosco, 2010); Children can aim to sustain their inclusion into society and resist their subject position of being 'deportable' at the same time.

But why should we study children's political agency to begin with? And why is the irregular situation interesting? According to Stuart Aitken, Ragnhild Lund and Anne Trine Kjørholt, children are an 'important fulcrum of, and impetus for, change' in a globalised world (2007, 
p. 3). Furthermore, Anne McNevin sees 'irregular migrants' acts of contestation as a new frontier of the political' (2011, p. 5). Inspired by this, I argue that studying what children do in an irregular situation may contribute to an understanding of how political agency is enacted by children even in, or perhaps especially in, the most vulnerable positions. Also, I aim to understand what change they themselves aspire for at this political frontier by acknowledging these children's struggles in their everyday lives.

Earlier research on the everyday lives of children and their families in an irregular situation has been conducted in Sweden (Ascher \& Wahlström Smith, 2016), the UK (Sigona \& Hughes, 2012) and most extensively in the US (Abrego, 2006; Dreby, 2015; Gonzales, 2016; Menjívar, 2006). These studies discuss to varying extent the coping strategies, resilience and agency of children but none of them engage in a discussion about how their struggles can be understood as contesting the irregular situation and thus being expressions of political agency. This article attempts to fill this gap and answer Fernando Bosco's call for more explorations between 'children, activism and political work in more explicit ways' (2010, p. 385).

The political agency that the children in this study express is to a large extent a reaction to the repressive situation of deportability they find themselves in and they would prefer not having to contest it, but rather live their lives without being subject to migration control. I do not aim to idealise or romanticise actions by the children concerned. My point of departure is that since the children I met are living under these circumstances it is important to recognise their struggles. I agree with Sana Nakata who suggests (in this journal) that 'an individual who has recognised political agency will be visible in political conflict, and his or her political actions will be recognised by others and become central to key debates' (2008, p. 23). However, it is also important to remember that increased visibility can also lead to an increased risk of deportation and I have handled this risk through a thorough discussion with my participants about anonymization and have made sure the parents are aware of these risks and fully agree on the family's participation in the study.

The article begins with positioning itself within the literature on children's political agency and discussing in more detail why the irregular situation is a specifically interesting case for studying how this political agency comes about. After a brief methodological discussion on the implications of the call for more empirical studies within this field, it shows, through ethnographic observations, how children contest the 'deportability' imposed on them. The article then argues for the importance of children's contextual knowledge for acts of contestations to occur and exemplifies these contestations through highlighting these children's everyday struggles for the right to decide on their own identity and belonging. Simultaneously, it highlights the duality of children's political agency in the irregular situation by contrasting these explicit contestations of the subject positions imposed on them with examples of how children with varying knowledge struggle to sustain the inclusion into society they experience.

\section{Children's political agency as it happens in the world}

It is a well-established fact, or even a 'mantra', within childhood research that children are social actors and have agency of various kinds in different situations (Tisdall and Punch, 2012), but there is no common understanding about what this agency actually implies. One could question if agency is a useful theoretical concept for understanding anything at all if it potentially could encompass any action enacted by any subject in any kind of situation. However, by narrowing down the discussion by adding a prefix such as political agency we can make this problem less prevalent. In this vein, Lorenzo Bordonaro (2012) argues for an urgent need of bringing in political and rights discourses into the debate around agency. He remarks that children's agency should be seen as a political project rather than an essentialised feature of individuals. I agree with Bordonaro and in this paper I will specifically argue, drawing 
primarily on the work of Kirsi Pauliina Kallio and Jouni Häkli, for the need to study how children's political agency comes about in the everyday lives of children in contrast to discussing what it is in an essentialised sense, since the how of political agency is possible to study empirically.

To understand what 'the political', or 'politics', is Hannah Arendt suggested that we need to focus on how political action happens 'in the world' (Arendt, 1958, ch. 10). Kallio and Häkli connect Arendt's point with an argument (drawing on Flyvbjerg, 2001) that children are a 'critical case' useful for furthering our understanding of how political action is expressed in everyday life (Kallio and Häkli, 2010). This means that studying children can help us understand on a more general level how the concepts of 'agency' and 'politics' are connected. To be able to study the critical case of children's political agency Kallio and Häkli then suggest that such research need to be empirically informed so that 'the meanings of the political' can be worked out in practice and not just in theory (Häkli and Kallio, 2014). They suggest that such empirical studies should focus on 'lived childhoods' and their 'political worlds', or contexts, and 'what kinds of dynamisms uphold and transform the political worlds where children act as competent agents' (Kallio and Häkli, 2011, p. 24).

What, though, from the perspective of political research is so special about children? To begin with, even though there are signs of this changing, they are mostly invisible in research on political agency as well as in transnational migration since the subject in such research is usually implied to be an adult. Such an 'adultism' leaves out half of the world's population as irrelevant non-subjects (Marshall, 2015; White et al., 2011). This fundamental exclusion from the polity turns childhood into a useful conceptual lens through which traces of the political processes that control the direction of history can be tracked. Still, it is not useful to just include children into the realm of adulthood without making note of the specificities of children's politics. Rather, by discussing those specificities we get a contextualised understanding of how political agency is lived out and experienced. Kallio separates children as political actors from adults by focusing on the everyday life experiences and practices of children rather than their 'reflective contemplations or moral judgements' (Kallio, 2007, p. 124), as Kallio and Häkli point out:

Children typically fail to measure up to adults' and institutional actors' rational argumentation and thus by necessity practice politics on other, often bodily, grounds $[\ldots]$ at the same time children are human beings thoroughly involved in meaning-making processes and identity construction, living their lives as actual members of institutions, communities and societies. This twofold position, resulting in a rather particular standpoint, forms the basis of children's politics. (Kallio and Häkli, 2010, p. 357)

The specific 'rationality' and more 'embodied' character of children's politics is a central aspect of the specificities that make children a critical case to study to enable a further understanding of 'the political'. Kallio and Häkli further reserve the concept of children's politics 'to those situations where children as intentional social beings relate to subject positions offered by parental (peer) cultural or institutional forces of socialization' (Kallio and Häkli, 2010, p. 357-358). The embodied response to the subject positions offered to children is then expressed in 'a myriad of ways, performed in banal practices' (Kallio and Häkli, 2011, p. 28, 31). Consequently, these 'banal practices' should be at the centre of our attention since children's mundane acts in their everyday lives always have the potential of being political (Kallio, 2009). To avoid this leading into a kind of 'political everything' of children's politics, Häkli and Kallio suggest that 'in each case it is explicated why certain agencies are to be considered politically relevant, and how the polis in question shapes this relevance' - the 'polis' here being defined as 'the relational realm of everyday politics' (Häkli and Kallio, 2014, p. 
$183,195)$ - and that one should not ask 'what is or is not political, but rather how things are political' (Kallio and Häkli, 2011, p. 26). This focus on the how rather than the what emphasises that an analysis of children's political agency should primarily be based on empirical observations of how children contest their subject positions they have been offered in the context they exist within.

One theme prevalent within the debate around children's political agency, that is of special interest for a study of the irregular situation, is children's identity construction, since children's identities and bodies are defined as a 'battleground' where they contest borders in their everyday lives (Aitken and Plows, 2010) and in so doing becoming 'actual members' of the polity (Kallio and Häkli, 2010). Aitken and Plows further argue that identities are relational and at the same time differentiated, which creates a 'terrain for tension and antagonism' and it is out of the 'everyday actions of living and surviving' that 'revolutionary imaginations' as a 'creative force' emerge (2010, p. 329). Identity-forming processes are rooted in childhood experience and especially 'younger migrant's' (i.e. teenager's) identities can put into question the location of 'home' and 'host' nations' (Dobson, 2009, p. 358). However, discussions around individuals' choices of how they wish to identify themselves ethnically is primarily concerned with how members within different ethnic groups can negotiate their ethnic affiliation (Song, 2003, p. 54) and does not connect this discussion with technologies of migration regulation where adaptation of children to the host country, and consequently their ethnic affiliation with its culture, is a central concept. Also, Jonathan Scourfield et al. explain how historically education has been used by nations to instil 'national consciousness into children' (Scourfield et al., 2006, p. 1). Children in an irregular situation go through this formation just like any citizen child. But at the same time they are supposed to be prepared for return to the country they or their parents migrated from at any time that the migration authorities might say so. This is one example of how children in an irregular situation have to manage contradictory subject positions offered to them and consequently express political agency, which I will discuss in more detail below.

\section{The political significance of the irregular situation}

The above review of the literature on children's political agency so far suggests that an analysis of the political agency of children should be empirically based and focus on how they contest the subject positions they are offered in their everyday contexts as it happens in the world, acknowledging how their actions may not be as reflective and intentional as the political actions of adults but how they at the same time are still part of meaning-making processes and identity construction. What is so special then with the irregular situation compared to other politicised contexts where children express political agency? The irregular situation is a construction of the state and there is a continuous growth of the 'deportation regime' in our increasingly securitized world (De Genova \& Peutz, 2010). One of the most important aspects of the irregular situation, in relation to political agency, is the way that the deportability of its inhabitants forces them to live camouflaged lives in society (Chauvin and Garcés-Mascareñas, 2014). Other politicised positions of children discussed in the literature differ mainly from the irregular situation in that they are more visible. For example, the Palestinian child is a strongly politicised visible figure (Marshall, 2015), street children in Cape Verde are part of a visible urban group (Bordonaro, 2012), child soldiers have their own optional protocol in the Convention on the Rights of the Child (Hyndman, 2010) etc.

In contrast, children in an irregular situation blend in with their peers on the outside, but on the inside their various knowledge about their potential deportability leads to a discrepancy of various strength between the children's own self image of being just like any other child and at the same time being under constant pressure from the threats of migration control (see 
Dreby, 2015; Young, 2013). The irregular situation is created by the polis as a kind of 'accepted exclusion' of its non-members that still exists within its territory (Sager, 2011, p. 40) and the children have to negotiate their position inside it as they are included in and excluded from society at the same time.

There are two main potential routes to regularisation, or out of 'camouflage' into 'visibility' and inclusion in the polity, for families who have not been granted, or are not eligible to apply for, asylum according to UK law. The first one is the ' 7 year rule', which could give a child leave to remain if she 'has lived continuously in the UK for at least 7 years (discounting any period of imprisonment) and it would not be reasonable to expect the applicant to leave the $\mathrm{UK}^{11}$, and the second one is the right to register as a British citizen after residing in the UK for the first 10 years of a child's life ${ }^{2}$. As I will show below, over such extended periods of time children defined as 'migrants' (even though they may be born in the UK) go through a process of identifying themselves with the local culture; they do not see the logic behind being seen as a deportable 'alien' when all they know is the country they have lived in for all, or a large part, of their lives. This process was acknowledged by the UK Upper Tribunal (Immigration and Asylum Chamber) in a court ruling about a Nigerian family where the children had lived in the UK for several years. The court recognised that in the course of such time roots are put down, personal identities are developed, friendships are formed and links are made with the community outside the family unit' ${ }^{3}$ (see Finch, 2013).

The fact that children's identities and affiliation defines their ability to stay in the society they have grown up in is one way in which the highly paradoxical nature of the irregular situation is expressed. Children in an irregular situation are, in the position of being children, seen as 'citizens in the making', but in the position of 'irregular migrants' they are deportable first and foremost; they are migrants first and children second (Crawley, 2006) even though children according to The Convention on the Rights of the Child are supposed to be persons under special protection with specific rights independent of their legal status ${ }^{4}$. The identity and belonging of children and their affiliation with the UK is the main path through which both the children and their parents eventually get regularised. For most of the families this is the last resort. National, cultural and ethnic identity processes then become the key to inclusion. In this way the identity construction of irregularised migrant children is on-going everyday politics.

The children's position in the irregular situation of families as a key to inclusion for the whole family makes the question of their political subjectivity a question about their whole existence, this points to the embedded nature of children's agency that I discuss further below. In most cases, the reason the family has not been granted, or is not at all in a position to claim, asylum is that they come from what is sometimes referred to as "safe countries of origin", such as for example Jamaica, Nigeria and India. The general situation in those countries makes it very unlikely that applicants will be able to argue that their individual situation fits the narrow criteria of deservingness in the UK asylum process, however bad their personal circumstances may be. Since adults have to spend 20 years ${ }^{6}$ in an irregular situation in the UK before they could be eligible for regularisation the hope of the family is that their children manage to perform the deservingness necessary. In this way, children in an irregular situation in the UK have to manage multiple subject positions such as deportable alien, citizen in the making, classmate and provider of regularization for the family at the same time. Below I will describe how children themselves talk and act in this position and how children's political agency comes about, but first I will briefly discuss what methodological consequences Kallio and Häkli's call for empirical studies of children's political agency have for my research project. 


\section{Methodology}

This study draws on ethnographic fieldwork conducted during six months in the winter of 2014-2015 in Birmingham, UK, and due to the limited time for fieldwork I approached potential participants through NGOs and various support networks who are working long term with destitute migrants. The Institute for Research into Superdiversity (IRiS) at the University of Birmingham generously shared many of their contacts with me around the city initially, and some of my key 'gatekeepers' at the organisations told me at the end of my fieldwork that my connection with IRiS was crucial for them as they assessed my request. It took almost the whole first three months to negotiate how I could work together with the organisations, not because they were negative to my research, but because I had to have my police records checked, go through volunteer training and just have time to get in contact with all the different groups that I deemed relevant for my research.

During my research I conducted interviews with members from 16 families with a total of 45 family members. To be able to observe as many nuances of these children's experiences as possible I employed a combination of child interviews, including creative methods such as five-field-mapping (see Samuelsson, Thernlund and Ringström, 1996) and timelines to facilitate discussion, parent interviews and participant observation. I attempted to sit down and talk to, and do various exercises with school-aged children in six of these families. Four of these families had been getting section $4^{7}$ or section $17^{8}$ support for a few months to a few years after having spent several years before that without the legal right to be in the UK. Some of them had periodically not been signing with the Home Office as they were required to do and some had been waiting for the Home Office to reply to their applications for several years just to be told finally that the application had never reached the Home Office due to the incompetence of the families' solicitors. One family did not receive any support but had been living in legal limbo for more than 10 years, on and off fighting the Home Office through different applications.

Some of the most interesting findings I made during my research did not happen during interview sessions with children but while spending social time with the families. I also experienced the importance of the 'embeddedness' of children and their parents' agency, which recognises the importance of 'parents as agents in children's lives' (Boehm, 2012, p. 120). It was especially important to talk to the parents first to understand the context of the families' situations, and some of the children's everyday experiences I refer to were retold to me by the children's parents as they shared anecdotes with me of things their children had said and done that had surprised them or had just stuck in their memory. Gaining this kind of knowledge demanded that I took enough time to develop trust, first through piggybacking on the credibility that the support organisations had given me by granting me access, and over time by showing my support to the families' situations.

A number of ethical issues like how to establish rapport emerged during my fieldwork. I had to explain my position of being involved in migrant justice work since many years and that I was supportive of their struggles to be able gain the trust of the families (see De Genova, 2005, ch 1; Hale, 2008). I have conducted member checks by showing the parents drafts of the article and engaging in discussions about my observations and how I could make sure all sensitive information was taken out. None of them disagreed with how I represented them in the text. However, I still do not claim to give a recollection of the children's everyday lives that is representative of their own perspectives, rather I acknowledge that the following ethnographic renderings consist of observations I made of the way I interpreted these events, and I have chosen to recollect moments from my interactions with these children that illustrate the general argument I try to make about how children's political agency can come about. 


\section{Children's political agency: Knowledge instils anger}

In my research a basic premise occurred to me as fundamental for an understanding of why and how the children acted and reacted in various ways, namely that their experiences of living in an irregular situation are affected by what they know about the context in which they live. There seemed to be a correlation between how much they knew with how angry they were. Two cases, Andrea and Loreana, stood out as the ones who were the most openly frustrated and angry with how the Home Office treated them, and their mothers both pointed out that the children had been reading letters from the Home Office in secret. 12-year-old Loreana had vented her frustration by composing a corresponding letter to the Home Office that she was planning on posting without telling her mother. However, her mother found out about it and it was later included in the new application the family sent in, which she also shared with me as I accompanied her family to a meeting with their pro bono legal advisor. Loreana preferred to communicate in writing and therefore I did not attempt to interview her verbally. However, I argue that her letter to the Home Office is remarkable in the way it offers an insight into the thoughts and feelings of a child expressing her own subjectivity while contesting the subject position of being deportable.

The opening line of the letter reads: 'Dear Home Office, I am writing to you to tell you how angry and upset I am.' She further writes that her anger stems primarily from the fact that the Home Office in their letters questions if she really is her mother's daughter and if she really was born and had lived her whole life in the UK. She feels that they treat them as 'animals' by unfairly making them wait for so long for the right to stay in the UK and she accuses them of 'not doing their job properly'. She points out that being a child does not mean that she cannot speak up against injustices and be angry at adults who do not treat them well. No one needs to tell Loreana that she has agency, she knows it herself quite well and she argues that her young age does not mean that she should not be listened to.

Loreana's concluding message to the Home Office is that they should at least give her mother permission to work so that she can provide for her children. She has understood that she is depending on the Home Office for her 'dreams to come true', and she appeals to them rhetorically by saying, 'my life is in your hands'. In this way, the letter is a political intervention by a child into the immigration process that will define the child's future. Loreana understands that the Home Office is the source of her problems and she does what is in her powers to affect their decision by highlighting what she sees as the unreasonableness of the situation for which they are largely responsible. Loreana is contesting the irregular situation by voicing her own concerns and arguing for the importance of her perspective as a child. In doing so she is questioning the subject position she has been placed in as deportable, countering it with her own self-described position where her and her family's endurance for more than 12 years forms the basis of her claim to stay in the UK.

The other child who had also been reading letters from the Home Office is 7-year-old Andrea. We first met just before Christmas in 2014 in the garden of the Homelessness Association where she was furiously screaming and throwing things to the ground since someone had been eating her cookies (I thought they were for everybody). During the following four months, as I met the family on an almost weekly basis, Andrea and I became friends and I got to follow a part of their on-going struggle as they went from living in hiding to being housed by the Children's Services while filing an asylum claim at the Home Office. We met over 15 times during my research, including several whole days at the Homelessness Association or on daytrips and we have kept in touch through emails and phone calls after I left.

After getting permission from her parents, I made attempts to interview Andrea a few times. However, her young age and restless personality did not fit the interview format and the crea- 
tive methods I had in mind, so most of the time we ended up playing hours and hours of the card game UNO in the office of the Homelessness Association, much to the relief of the weekly women's group her mother attended next door. Still, I got to experience her perspective through many other activities, like talking to her mother about their experiences - in particular of dealing with the social services, watching her perform a monologue about her situation in a drama set up by the women's group, and just hanging out for hours in her home or on different trips and days out. One day when we were on our way to visit Cadbury World we stopped by a pond where some elderly English men were racing their radio-controlled sailing boats. Suddenly, out of nowhere, as a playful echo from her role in the drama group, Andrea stood up and exclaimed loudly ' $\mathrm{Mr}$ and Ms Duck, I hereby acknowledge to you that you have been accepted for support from the Migrant Support destitution fund!'

This awareness of the circumstances of her situation at the early age of seven originates in a meeting that the Home Office set up for her and her family where the Home Office were very keen that Andrea took part so that they could explain to her that her parents' visa had run out and that they were going to send them to Senegal, a country Andrea has never visited. As a consequence of Andrea's knowledge about the ' 7 year rule', her mother Tabitha recalled, the first question she asked on her $7^{\text {th }}$ birthday was: 'Mummy, are they still going to ask me to leave even though I am seven now?' Her own thoughts about her situation are perhaps best expressed in the short monologue she performed in the women's group's drama at two different occasions during my fieldwork.

Andrea: I am seven, I look like a normal child but I know I am different. I move around with my parents, sleeping here today and there tomorrow. I don't have any friends in my age, I change schools all the time. I keep my parents happy. I was born in the UK and I have been here all my life, all I know is this country, this is my country why can't I live here?

Even though the leader of the drama group wrote the exact words, Andrea explained to me that they were true - they are her own experiences. Her deportability is contrasted by the fact that she is a member of the children's parliament at her school and her head teacher praises her for her learning outcomes and calls her 'a credit to our school' in the yearly evaluation letter. Still, Andrea is very aware of her deportability and she contests this subject position in every way she can imagine, which I will come back to below, but first I want to complement Loreana and Andrea's experience with a child who, according to her father, did not know anything about her deportability during my research.

\section{Children's political agency: Ignorance is bliss?}

The parents of Sunayah, a 14-year-old from Pakistan, had made every effort to keep their children unaware of the problems the family was facing. The immigration history of the family is complex. Fadi, Sunayah's father, came with his wife and, at the time, 2-year-old only child Sunayah and applied for asylum in 2002. Their claim was rejected and they went back to Pakistan in 2004, just to come back again soon after with two children (now 4 and 1 years old), but this time they chose not to apply for asylum but managed to stay clandestine for six years. During this time the father was able to find cash-in-hand jobs to keep the family afloat, but when he lost his job and things got harder they decided to claim asylum again in 2010. As they did not hear anything from the Home Office for two years they went to their MP in 2012 who found out that the Home Office had never received any application - the incompetency of their initial corrupt solicitor had wasted two years for them. When I first met them they had been waiting for three years for an answer to their asylum claim. 
Throughout this time the parents had never talked to their children about their immigration status, and I was also able to talk with Sunayah about the different phases they had gone through without mentioning their irregular immigration status by referring to the different houses they had lived in. The moving of houses coincided with their changing of status from living clandestinely to applying for asylum and receiving section 4 support. She had noticed that her parents had become more stressed since they moved to the current house (after having their asylum application registered properly) and Fadi confirmed this, saying:

Fadi: When you live illegally [...] I have only one stress: how to live, how to earn money. [...] But when I am an asylum seeker, everyday I have a new stress. Is the postman coming or not coming? If he comes, what will he drop? Or the Home Office will deport me?

The change from living in their old house to moving into the new one was sudden and unexpected for Sunayah since no one really explained to her why they had to move. But she told me that she does not really ask her parents about those things; she has enough to worry about with school exams since she wants to get good grades so that she can be a paediatrician some day. The situation with the house and the long travel to school she cannot do anything about anyway, she said, 'Yeah that's not exactly in my power so if I can't do anything about it there is no point worrying about it, that's kind of what I go for.' She said that she's glad that she does not know much about the details about their situation since it would probably only make her more stressed and worried. The impeccably well-behaved and well-mannered daughter and the friendly and hospitable attitude of her parents gave me the impression that the unawareness that Sunayah possessed was favourable for her aim to focus on school and get on with life. I was perplexed by the fact that the parents had been able to keep this knowledge away from her.

Before a return trip to Birmingham a few months after my initial fieldwork I had sent a text to Fadi with reflections about the family's situation. Fadi had then chosen to show this text to Sunayah since he felt that she was old enough to know now. I then asked Sunayah if she had any thoughts about the text but she only laughed nervously and said 'no'. Before I left them, Fadi told me that he had not discussed the text with her either after she had read it. Sunayah kept her thoughts and feelings about their immigration status to herself, and she probably did the same before she read my text as well; after all she has been brought up in a family where certain things are not talked about. Since I did not want to reveal too much to her about her deportability during my initial fieldwork I was not able to invest the time necessary to gain the trust needed for her to potentially reveal more of what she actually thought and felt about the family's situation. However much she may have known, it was still clear that her apparent lack of knowledge correlated with a lack of visible anger and, consequently, absence of action, as compared to Loreana and Andrea. But as I will discuss further in the conclusion, political agency can also be expressed through attempts to stabilise and protect one's everyday life as it is. Even though the waiting has been hard to endure, in the end it turned out to be beneficial to them. After I finished my fieldwork the family was granted asylum and, according to Fadi, the fact that Sunayah's 9-year-old brother in a few months would have been eligible for British citizenship probably had a strong influence on that decision.

\section{Children's political agency: Identity-struggles as everyday politics}

I will now return to Andrea and show how her anger about the irregular situation is connected with the question of her national identity. Due to the complex and restrictive immigration rules, children in an irregular situation end up spending many years in the UK with varying legal statuses over time and in the meantime go through a process of affiliating themselves with the UK context and increasingly identifying oneself as British. In my fieldwork, this was 
especially clear in the case of Andrea who was born in the UK and has never left its shores. Her skin is dark like her parents' but her childhood has mostly been spent in predominantly white areas. She does not speak her parents' Senegalese dialect and gets rather upset when they use a language she cannot understand. During one of the gatherings at the Homelessness Association I watched a participant tease her: 'You are African,' he said with a smirk on his face, 'No I am British!' Andrea replied angrily. 'You are African,' he repeated with his cheeks growing further apart, 'No I am British!' Andrea exclaimed forcefully as she angrily started hitting and kicking him. Amused by the girl's increased fury the man once again repeated, now laughing, 'You are African!' and by now Andrea had forced herself on top of him in his chair, 'NO I AM BRITISH!' she screamed to his face without any trace of fun in her voice, but rather expressing a strong resentment and experience of being abused.

The social services had grown increasingly concerned about Andrea's 'lack of acceptance of her African identity' as her mother Tabitha recalls them saying, 'if worse comes to worse and you were told you need to leave she's going to really struggle with even the concept of going' they told her. Tabitha believes that Andrea's habit of secretly reading letters from the Home Office might be one explanation for her concern about her right to define her own identity and belonging.

Tabitha: She's British, there is nothing African in her, NOTHING African in her [...] she just doesn't want to hear the word black. [...] She says, 'my mum can be an African but I'm not, I'm British' [...] 'Mummy why are they trying to say we are not the same, they say we're Africans, I wasn't born in Africa, I was born here, I'm British, why do they say I'm African?' [...] She's got this fear of living where she's never been cause she's never been there and she keeps asking me 'what's your country like compared to where we are now?' [...] But I try to make her think positive that everything will be fine.

Tabitha recalled various interventions where the social workers were trying to offer Andrea a complimentary subject position of being African as well as British and to make Andrea think more positively about 'Africa' and 'Africans'. The politics of race and ethnicity and its connection to the bordering and formation practise of the UK as a nation cuts right into Andrea's irregular situation. The social workers' ideas about the importance of an ethnic identity that is in line with blood ties and skin colour is connected with an idea that Andrea should be prepared for the worst case scenario of being deported to Senegal with her family. By reading the letters from the Home Office, Andrea has gotten the impression that they question her British identity. Neither the Social Services nor her mother know exactly what Andrea's idea about what being 'British' or 'African' is. For Andrea, the question about her identity and her right to live in the UK are tightly connected and it is not hard to understand that she contests the notion of her being an African when she makes this connection. The threat of being deported to a place where she has never been has entered into her world and as a young child she reacts in the ways she can to show that she disagrees with the identity and subject position she is being offered.

Andrea's contestation of the irregular situation is a part of her everyday life, but it is also expressed on public political arenas, such as when she performs a monologue about her life on a church stage and stirs up reactions in the audience of repugnance towards the way children are being treated in the UK. My conviction that 7-year-old Andrea should be acknowledged as a political subject of her own was fittingly further verified as I had finished my fieldwork and received a photo from her mother of Andrea standing next to Natalie Bennet, the Green Party leader, outside Yarl's Wood detention centre as she took part in a demonstration to end the detention of women. Holding a bright yellow trumpet in her hand and looking into the 
camera with a cheeky smile she reminds us of how even a 7-year-old can understand and contest the irregular situation and even rightly be called an activist in her own way.

\section{Conclusion}

In this article I have shown how children in an irregular situation contest the subject positions they are put in, most centrally the position of being 'deportable', but also the position of not being seen as 'British', and how they suggest their own definitions of who they are and where they belong. Their liminal position of being deportable and at the same time 'citizens in the making' makes these children's actions and perceptions a fruitful case for understanding how political agency of children comes about. I agree with Bosco (2010) that we should focus on what these children do rather than who they are. Andrea channels her frustration through happily engaging in her parents' creative activities of putting on dramas and taking part in demonstrations, but also through consistently challenging anyone who questions her own perception of her identity. Loreana expresses her anger through writing letters to the Home Office, attacking their incompetency and the unreasonableness of their decisions.

Both Andrea and Loreana's contestations are connected to their relatively extensive knowledge about their immigration status, whereas Sunayah attempts to uphold a position of ignorance towards her legal status so that she does not waste her energy on worrying about things she feels she cannot change. She reminds us of what Saba Mahmood points out, namely that 'agentival capacity is entailed not only in those acts that result in (progressive) change but also in those that aim toward continuity, stasis, and stability' (2001, p. 212). The children's struggle for inclusion and 'normality' are in part expressions of this longing for continuity of the inclusion they experience in their everyday lives. This dual aspect of children's political agency is often overlooked in research, where explicit examples of resistance by children such as Andrea and Loreana are the focus of attention, effectively muting the voices of the very real struggle of children who try to make their life work in difficult circumstances in less audible ways, like Sunayah. Also, Andrea and Loreana point to their experience of being included when they define themselves and argue for their belonging - in this way the duality of their political agency is not a contrasting phenomena but rather complementary; The inclusion of most irregularised migrant children into society is the basis for their claims to belong and their knowledge about the discrepancy between their inclusion and their deportability the starting point for how they more actively contest the irregular situation.

In this article I have not intended to idealise the political agency of these children, rather, I want to emphasise that it comes about as a reaction to the repressive context of deportability that no-one should have to experience. Thus, the point in highlighting how political agency of children in an irregular situation comes about is not just to theorise around the notion of irregularity and children as political subjects, but to also lift their voices and acts of contestation into the public debate so that they can inform and affect the way the debate is formed, and challenge the very constitution and existence of the irregular situation. Politics takes place in children's everyday lives and studying politicised positions such as those created by the irregular situation recognises children's struggles as they happen in the world.

\section{Acknowledgments}

The author wants to thank the participants for their willingness to let him take part in their everyday lives. Furthermore, this article was written with the invaluable support of the author's PhD supervisors, Dr Anna Lundberg and Dr Michael Strange. The author also wants to thank the three anonymous reviewers for their constructive comments. 


\begin{abstract}
About The Author
Jacob Lind is a PhD student in Global Political Studies and part of the doctoral programme Migration, Urbanisation and Societal Change (MUSA) at Malmö University. His research engages with current debates within critical migration studies, the geographies of childhood and critical human rights studies. His on-going dissertation work is a comparative ethnographic study of the everyday lives of irregular migrant children and their families in Malmö, Sweden, and Birmingham, UK.
\end{abstract}

Jacob Lind, Malmö University, 20506 Malmö, Sweden

jacob.lind@mah.se, +46(0)707975945

\title{
Notes
}

(1) Home Office Immigration Rules 276ADE(iv).

(2) Section 1(4) of the British Nationality Act 1981.

(3) http://www.bailii.org/uk/cases/UKUT/IAC/2011/00315_ukut_iac_2011_ea_others_nig eria.html

(4) Article 2.1

(5) http://ec.europa.eu/dgs/home-affairs/what-we-do/policies/european-agendamigration/background-information/docs/2_eu_safe_countries_of_origin_en.pdf

(6) Home Office Immigration Rules 276ADE(iii).

(7) Section 4 support is provided by the Home Office to, amongst others, refused asylum seekers who cannot yet be deported but who are 'taking all reasonable steps to leave the UK' or to whom 'provision of accommodation is necessary for the purpose of avoiding a breach of a person's Convention rights'. See:

https://www.gov.uk/government/uploads/system/uploads/attachment_data/file/438472 /asylum_support_section_4_policy_and_process_public_v5.pdf

(8) Section 17 support is given by local authorities to families with 'children in need', including children with no immigration status on humanitarian grounds. See: http://www.project17.org.uk/resources/guide-to-accessing-support/are-you-eligiblefor-support/

\section{References}

Abrego, L. J. (2006). I Can’t Go to College Because I Don't Have Papers: Incorporation Pattterns Of Latino Undocumented Youth. Latino Studies, 4(3), 212-231.

Aitken, S. C., Lund, R., \& Trine Kjørholt, A. (2007). Why Children? Why Now? Children's Geographies, 5(1-2), 3-14.

Aitken, S. C., \& Plows, V. (2010). Overturning assumptions about young people, border spaces and revolutions. Children's Geographies, 8(4), 327-333.

Arendt, H. (1958). The human condition. Chicago: University of Chicago Press.

Ascher, H., \& Wahlström Smith, Å. (2016). ”Bli inte hopplösa” En studie om vardagsstrategier hos barn på flykt i en papperslös situation. Retrieved 160518 from http://www.allmannabarnhuset.se/wp-content/uploads/2016/04/Bliintehopplösa.pdf 
Boehm, D. A. (2012). Intimate migrations: gender, family, and illegality among transnational Mexicans. New York: New York University Press.

Bordonaro, L. I. (2012). Agency does not mean freedom. Cape Verdean street children and the politics of children's agency. Children's Geographies, 10(4), 413-426.

Bosco, F. J. (2010). Play, work or activism? Broadening the connections between political and children's geographies. Children's Geographies, 8(4), 381-390.

Chauvin, S., \& Garcés-Mascareñas, B. (2014). Becoming Less Illegal: Deservingness Frames and Undocumented Migrant Incorporation: Becoming Less Illegal. Sociology Compass, 8(4), 422-432.

Crawley, H. (2006). Child First Migrant Second: Ensuring that every child matters. London: Immigration Law Practitioners' Association.

De Genova, N. (2002). Migrant "Illegality" and Deportability in Everyday Life. Annual Review of Anthropology, 31(1), 419-447.

De Genova, N. (2005). Working the boundaries: race, space, and "illegality" in Mexican Chicago. Durham, N.C: Duke University Press.

De Genova, N., \& Peutz, N. M. (Eds.). (2010). The deportation regime: sovereignty, space, and the freedom of movement. Durham, NC: Duke University Press.

Dobson, M. E. (2009). Unpacking children in migration research. Children's Geographies, $7(3), 355-360$.

Dreby, J. (2015). Everyday illegal: when policies undermine immigrant families. Oakland, California: University of California Press.

Finch, N. (2013). Routes to regularisation for people without legal status in the UK. Garden Court Chambers. Retrieved 160518 from http://www.phf.org.uk/publications/routesregularisation-people-without-legal-status-uk/

Flyvbjerg, B. (2001). Making social science matter why social inquiry fails and how it can succeed again. Oxford, UK; New York: Cambridge University Press.

Gonzales, R. G. (2016). Lives in limbo: undocumented and coming of age in America. Oakland, California: University of California Press.

Häkli, J., \& Kallio, K. P. (2014). Subject, action and polis: Theorizing political agency. Progress in Human Geography, 38(2), 181-200.

Hale, C. R. (Ed.). (2008). Engaging contradictions: theory, politics, and methods of activist scholarship. Berkeley: University of California Press.

Hyndman, J. (2010). The question of "the political" in critical geopolitics: Querying the "child soldier" in the "war on terror." Political Geography, 29(5), 247-255.

Kallio, K. P. (2007). Performative Bodies, Tactical Agents and Political Selves: Rethinking the Political Geographies of Childhood. Space and Polity, 11(2), 121-136.

Kallio, K. P. (2009). Between social and political: children as political selves. Childhoods Today, 3(2).

Kallio, K. P., \& Häkli, J. (2010). Political geography in childhood. Political Geography, 29(7), 357-358.

Kallio, K. P., \& Häkli, J. (2011). Are There Politics in Childhood? Space and Polity, 15(1), 21-34. 
Mahmood, S. (2001). Feminist theory, embodiment, and the docile agent: Some reflections on the Egyptian Islamic revival. Cultural Anthropology, 16(2), 202-236.

Marshall, D. J. (2015). Existence as Resistance: Children and Politics of Play in Palestine. In K. Kallio, S. Mills, \& T. Skelton (Eds.), Politics, Citizenship and Rights (pp. 1-15). Singapore: Springer Singapore.

McNevin, A. (2011). Contesting citizenship irregular migrants and new frontiers of the political. New York: Columbia University Press.

Menjívar, C. (2006). Liminal Legality: Salvadoran and Guatemalan Immigrants' Lives in the United States 1. American Journal of Sociology, 111(4), 999-1037.

Nakata, S. M. (2008). Elizabeth Eckford's appearance at Little Rock: the possibility of children's political agency. Politics, 28(1), 19-25.

Sager, M. (2011). Everyday clandestinity: experiences on the margins of citizenship and migration policies (Doctoral thesis). Lund University, Lund, Sweden.

Samuelsson, M., Thernlund, G., \& Ringström, J. (1996). Using the five field map to describe the social network of children: A methodological study. International Journal of Behavioral Development, 19(2), 327-345.

Scourfield, J., Dicks, B., Drakeford, M., \& Davies, A. (2006). Children, place and identity: nation and locality in middle childhood. London; New York: Routledge.

Sigona, N., \& Hughes, V . (2012). No Way Out, No Way In. Oxford: ESRC Centre on Migration, Policy and Society.

Song, M. (2003). Choosing ethnic identity. Cambridge, UK : Malden, MA: Polity Press ; Blackwell Pub.

Tisdall, E. K. M., \& Punch, S. (2012). Not so "new”? Looking critically at childhood studies. Children's Geographies, 10(3), 249-264.

White, A., Ní Laoire, C., Tyrrell, N., \& Carpena-Méndez, F. (2011). Children's Roles in Transnational Migration. Journal of Ethnic and Migration Studies, 37(8), 1159-1170.

Young, J. (2013). "This is my life": Youth negotiating legality and belonging in Toronto. In L. Goldring \& P. Landolt (Eds.), Producing and Negotiating Non-citizenship: Precarious Legal Status in Canada (p. 99). Toronto: University of Toronto Press. 